\title{
Towards a better quantitative assessment of the relevance of deep-sea viruses, Bacteria and Archaea in the functioning of the ocean seafloor
}

\author{
R. Danovaro ${ }^{1,2, *}$, C. Corinaldesi ${ }^{1}$, E. Rastelli ${ }^{1,2}$, A. Dell'Anno ${ }^{1}$ \\ ${ }^{1}$ Department of Life and Environmental Sciences, Polytechnic University of Marche, Via Brecce Bianche, 60131 Ancona, Italy \\ ${ }^{2}$ Stazione Zoologica Anton Dohrn, Villa Comunale, 80121 Naples, Italy
}

\begin{abstract}
The deep-ocean interior contains the majority of microbes present on Earth. Most deep-sea microbes are concentrated in surface sediments, with abundances up to 4 orders of magnitude higher, per unit of volume, than in highly productive waters of the photic zone. To date, it has been shown that prokaryotic biomass largely dominates over all other biotic components, but the relative importance of Bacteria, Archaea and viruses to the global benthic biomass has not yet been quantified. Here, we report that the microbial abundance in the top $50 \mathrm{~cm}$ of deep-sea sediments of the world oceans is on the order of $1.5 \pm 0.4 \times 10^{29}$. This is largely represented by viruses $\left(9.8 \pm 2.5 \times 10^{28}\right)$, followed by Bacteria $\left(3.5 \pm 0.9 \times 10^{28}\right.$ cells $)$ and Archaea $\left(1.4 \pm 0.4 \times 10^{28}\right.$ cells). The overall biomass in the top $50 \mathrm{~cm}$ of the deep-sea sediments is $1.7 \pm 0.4 \mathrm{Pg} \mathrm{C}$, largely represented by bacterial biomass (ca. $78 \%$ ), followed by archaeal biomass (ca. $21 \%$ ) and viruses $(<1 \%)$. The bathymetric patterns of abundance and biomass of the 3 microbial components show differences: abundance and biomass of Bacteria decrease with increasing water depth, whereas those of Archaea and viruses remain constant. These results support the hypothesis that the role of Archaea and viruses could be more relevant in the deepest part of the ocean floor.
\end{abstract}

KEY WORDS: Ecosystem functioning - Biogeochemical cycles · Prokaryotes - Viral infection · Marine sediments

Resale or republication not permitted without written consent of the publisher

\section{INTRODUCTION}

The 'deep sea' includes the waters and sediments of the ocean interior beneath approximately $200 \mathrm{~m}$ depth, representing more than $65 \%$ of the Earth's surface and ca. $95 \%$ of the global biosphere (Gage \& Tyler 1991). Despite the huge dimensions and ecological importance of deep-sea habitats, our knowledge on deep-sea microbiology and its role in ecosystem functioning is still limited. Current estimates report that only $5 \%$ of the deep oceans have been explored in detail so far, and that less than $0.001 \%$ has been sampled and described in terms of microbiology and biodiversity (Rex et al. 2006, Wei et al.
2010). Even less is known about the functioning of, and the interactions between, biodiversity and ecological processes in the deep seas (Danovaro et al. 2014, Mora et al. 2014). The development of advanced instrumentation for observing, mapping and sampling the seabed and all of its features has enabled scientists to develop a picture of the deepsea environment as a highly dynamic geo- and biosphere. Besides the vast deep-sea flat and muddy plains and their subsurface, the ocean seafloor is characterized by high habitat complexity and heterogeneity (Ramirez-Llodra et al. 2010). A variety of highly diverse landscapes have been recently described, including canyons, seamounts, ridges, fur- 
rows, deep-water coral reefs, cold seeps, pockmarks, mud volcanoes, carbonate mounds, fractures and trenches that host rich and highly diversified microbial assemblages. Compared with the water column, the ocean seafloor provides a wider area of solid surfaces composed of biogenic, terrigenous, volcanogenic particles, with heterogeneous pore spaces, as well as a higher concentration of organic matter per unit volume (Danovaro et al. 2014).

Along with the export of organic material from the photic zone, geological processes transport chemical energy (hydrogen, methane, hydrogen sulphide, iron) up to the seafloor from the subsurface below. At the sites on the seafloor where chemical energy is particularly high, rich and diverse microbial assemblages are typically found, such as in hydrothermal vents and cold seeps (Cavanaugh 1985, Jørgensen \& Boetius 2007). However, microorganisms inhabiting the subsurface of the ocean floor live in conditions of extreme energy limitation, with mean generation times up to thousands of years (Hoehler \& Jørgensen 2013), depending only on the small amount of the organic carbon buried in deep-sea sediments (Lutz et al. 2007) and on chemoautotrophic processes (D'Hondt et al. 2002, 2004).

Although the scientific discovery of the ubiquity and enormous abundance of microorganisms dates back to the 1860s, microbes inhabiting the deep sea started to be studied in detail only in the 1950s, along with the appearance of the first historical monographs on marine microbiology (e.g. Benecke 1933).
In the 1950s, deep-sea samples that were gathered on the Danish 'Galathea' Deep-Sea Expedition from depths of more than $10000 \mathrm{~m}$ were shown to host millions of viable Bacteria per gram of sediment, confirming that pressures up to more than 1000 times higher than atmospheric pressure do not exclude the possibility for life to evolve (ZoBell \& Morita 1959). Subsequent studies conducted in the 1980s and 1990s that were aimed at quantifying the microbial assemblages demonstrated their activity in the deep ocean interior (Jannasch \& Taylor 1984, Alongi 1990, Deming \& Baross 1993, Yayanos 1995). Most deepsea microorganisms are extremely difficult to cultivate, due to their slow in situ growth rates and their likely strict adaptation to extreme environmental conditions (oligotrophy, low temperatures and high in situ pressures or anoxia). The number of pure cultures that are available is limited to a few hundred species, and the cultivation of microorganisms under high pressure has been achieved only in a limited number of cases (Kato 2011).

\section{ECOLOGICAL ROLE OF MICROBES IN THE DEEP SEAFLOOR}

In recent years, enormous progress has been made in the investigation of deep-sea microbes and their functional role, and an increasing portion of the deep seafloor has been sampled (Fig. 1). The analysis of these samples has revealed that deep

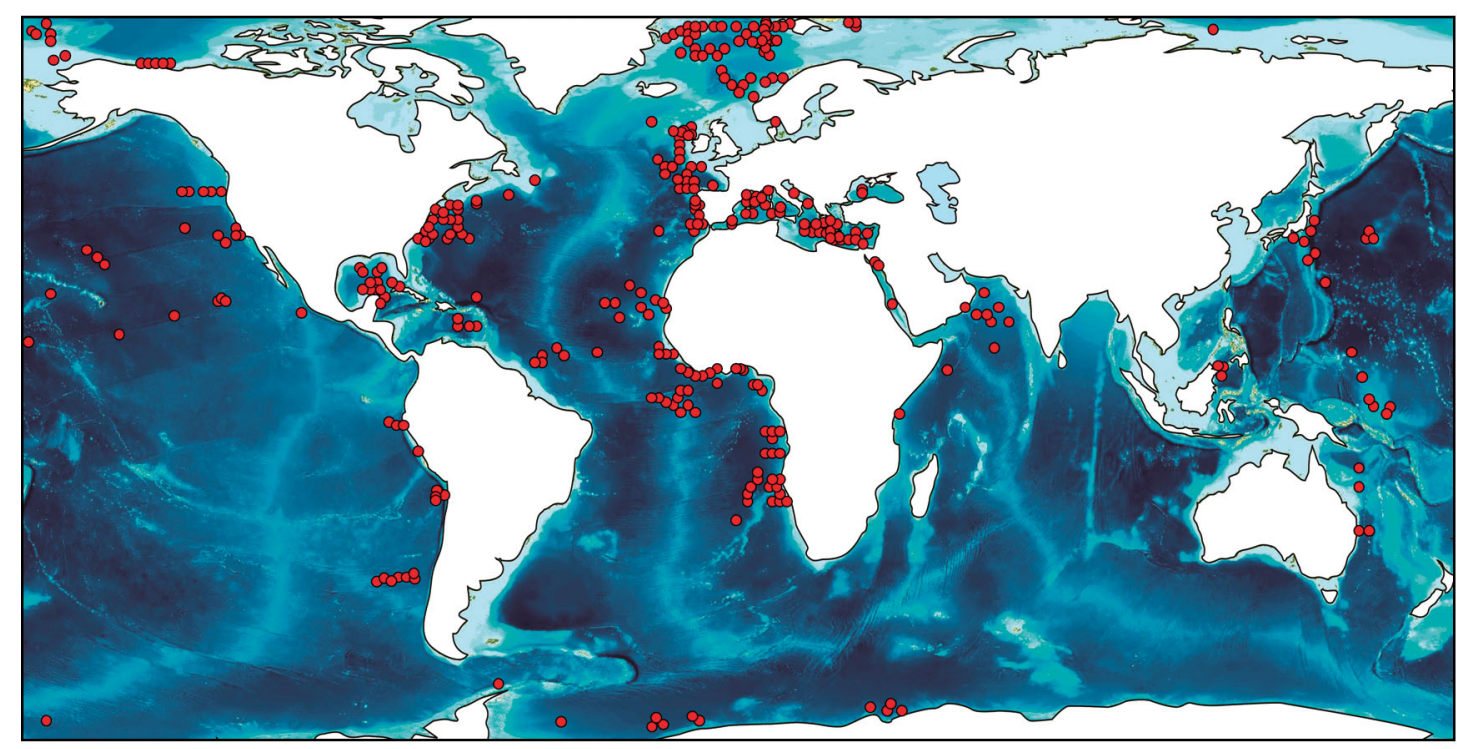

Fig. 1. Sampling sites of deep-sea surface sediments analysed to date and considered in the present study (data from Middelboe et al. 2006, Rex et al. 2006, Danovaro et al. 2008b, Molari et al. 2013, R. Danovaro unpubl. data) 
surface sediments, at all depths, contain 10- to 10000 -fold more cells per unit volume than productive ocean-surface waters (Whitman et al. 1998). It is thus now evident that prokaryotes represent the largest pool of biomass in the world oceans (Rex et al. 2006, Wei et al. 2010), and that they contribute to the biogeochemical cycles in several fundamental ways, thus playing a key role in deep-sea ecosystem functioning (Nealson 1997, Mason et al. 2009, Arndt et al. 2013). Besides prokaryotes, other microscopic biological entities, viruses, are also known to play a major role in nutrient cycling and transfer of energy to higher trophic levels, both in the water column and sediments (Suttle 2005, 2007, Danovaro et al. $2008 a, b)$. Not being able to self-replicate, viruses invade other organisms and use their cells' machinery to propagate (Suttle 2005). They can infect all known life forms in the oceans, from the smallest marine microbes to the largest mammals (Rohwer \& Thurber 2009). Since prokaryotes are the predominant life forms in the deep oceans in terms of biomass, the interactions between viruses and members of the 2 prokaryotic domains (i.e. Bacteria and Archaea) are considered among the most relevant processes driving ecosystem functioning on the global scale (Proctor \& Fuhrman 1990, Fuhrman 1999). The prokaryotic biomass represents a potentially enormous food source for higher trophic levels in deep-sea food webs (Dell'Anno \& Danovaro 2005). However, since heterotrophic consumers belonging to meio-, macro- and mega-fauna decrease exponentially with increasing water depth (Rex et al. 2006), the potential role of viruses in controlling microbial components increases in the deep ocean interior (Danovaro et al. 2008b). Viral ecology is a crucial field in deep-sea microbiology, largely neglected thus far, and is only now starting to be included in global models of carbon, nitrogen and phosphorus cycling and nutrient fluxes (Jover et al. 2014, Dell'Anno et al. 2015). By killing their hosts, viruses can transform the living biomass into organic detritus (mostly dissolved organic matter, DOM); this can then be used again by other microbes, stimulating their growth. This process has been termed 'viral shunt' (Suttle 2005, 2007) and, depending on the balance between the abatement of living cells and the stimulation of the metabolism of the survivors, it can either fuel prokaryotic heterotrophic and autotrophic production by releasing DOM and enhancing nutrient regeneration pathways, or it can also decrease the efficiency of the carbon transfer to higher trophic levels. The debate on this topic is still open among marine ecologists.

\section{MICROBIAL ABUNDANCE, BIOMASS AND DISTRIBUTION IN THE OCEAN SEAFLOOR}

Whitman et al. (1998) made a global estimate of the number of prokaryotic cells that are present in the oceans, from the sea surface to the subsurface sediments. They concluded that deep-sea microbes represented the 'hidden majority' of all life forms, comprising between 50 and $\sim 80 \%$ of the Earth's total microbial biomass and between 10 and $30 \%$ of the Earth's total living biomass (Teske 2005). Studies conducted on sediment cores, within the frame of the Integrated Ocean Drilling Program expeditions, provided information on the number, biomass and activity of prokaryotes below the sediment surface, revealing the presence of metabolically active microorganisms several hundred metres below the ocean floor (Cragg et al. 1990, Parkes et al. 2000, D'Hondt et al. 2002, 2004, Teske 2005). A more recent meta-analysis on the available information from the ocean surface to the deepsea subsurface sediments indicates that the average cell numbers and activities decrease exponentially with depth (both in the water column and in the sediment; Lloyd et al. 2013). Archaea have been assumed for a long time to be a minor portion of the total microbial assemblages in the oceans and in the seafloor. Subsequent works highlighted that archaeal abundance, not only in deep-sea waters beneath $1000 \mathrm{~m}$ depth but also in subsurface sediments, can equal bacterial abundance or even dominate the assemblages (Karner et al. 2001, Schippers et al. 2005, Biddle et al. 2006, Schippers \& Neretin 2006, Lipp et al. 2008, Lloyd et al. 2013, Xie et al. 2013).

However, information on the relative importance of Bacteria and Archaea and their biomass in marine sediments is still limited (Kallmeyer et al. 2012, Xie et al. 2013), and even less is known about the contribution of viruses to the total microbial benthic biomass (Anderson et al. 2013, Engelhardt et al. 2014). The first investigations of global trends in the distribution and abundance of microbial cells showed that the abundance of cells in surface sediments is usually related to the input of fresh detritus, rather than to any other environmental variable (Deming \& Baross 1993, Smith et al. 1997, Boetius \& Damm 1998). It was generally assumed that the abundance and biomass of the microbial components are controlled by the quantity and quality of the available organic substrates. This applies to most biological components in the deep sea (e.g. meiofauna macrofauna, megafauna), and since the availability of food and resources typically decreases with increasing water depth (Danovaro et al. 1998), the biomass of all fau- 
Table 1. Output of the regression analyses of the abundance and biomass for Bacteria, Archaea and viruses vs. water depth. ${ }^{*} \mathrm{p}<0.05$, ns: not significant; N: no. of observations

\begin{tabular}{|lccccc|}
\hline \multicolumn{1}{c}{ Equations } & $\mathrm{R}^{2}$ & $\mathrm{~N}$ & $F$ & $\mathrm{p}$ \\
\hline Abundance & & & & & \\
Bacteria & $y=5.40 \times 10^{8}-\left(5.49 \times 10^{4}\right) X$ & 0.024 & 222 & 5.41 & $*$ \\
Archaea & $y=1.08 \times 10^{8}+\left(4.05 \times 10^{2}\right) X$ & $<0.01$ & 219 & $<0.01$ & $\mathrm{~ns}$ \\
Viruses & $y=9.38 \times 10^{8}+\left(9.26 \times 10^{3}\right) X$ & $<0.01$ & 232 & $<0.20$ & $\mathrm{~ns}$ \\
Biomass & & & & & \\
Bacteria & $y=1.98 \times 10^{4}-2.01 x$ & 0.027 & 222 & 6.12 & $*$ \\
Archaea & $y=2.71 \times 10^{3}+\left(1.01 \times 10^{-2}\right) x$ & $<0.01$ & 219 & $<0.01$ & $\mathrm{~ns}$ \\
Viruses & $y=1.88 \times 10^{2}+\left(1.85 \times 10^{-3}\right) X$ & $<0.01$ & 232 & $<0.10$ & $\mathrm{~ns}$ \\
\hline
\end{tabular}

from the shelf-break down to the abyssal depths (Danovaro et al. 2008a,b, Siem-Jørgensen et al. 2008). Results presented here indicate that while the abundance and biomass of Bacteria showed a decreasing pattern (negative slope coefficients) with increasing water depth, the abundance and biomass of viruses and Archaea did not decrease (Fig. 2A,B, Table 1). In contrast, a decreasing pattern along the vertical profile of sediment was observed for all microbial components investigated (Fig. 2C-E). If the available data provide the first insights on the bathymetric patterns of benthic micro-

nal components decreases exponentially (Rex et al. 2006). However, in the same work, Rex et al. (2006) demonstrated that benthic Bacteria only barely decreased with increasing water depth.

Viruses inhabiting deep-sea ecosystems are quantitatively far more important than was assumed only 2 decades ago. Now, we know that viruses are the most abundant biological entities of the oceans, outnumbering prokaryotes by at least 1 order of magnitude (Suttle 2005, 2007). Current estimates are in the order of $10^{30}-10^{31}$ viruses in the water column (Suttle 2005, 2007), and available information demonstrates that viruses are also highly abundant and active in deep-sea sediments (Middelboe et al. 2006, 2011, Danovaro et al. 2008b).

Analysis of the spatial patterns of prokaryotic abundance and biomass suggests that they do not decrease significantly with increasing water depth as observed for mega-, macro- and meiofauna, (Rex et al. 2006). The meta-analysis we conducted on available benthic data confirms that prokaryotic and viral abundances are high at all depths in the deep sea,

Fig. 2. Bathymetric patterns for (A) abundance and (B) biomass of Bacteria, Archaea and viruses in surface deep-sea sediments (top $1 \mathrm{~cm}$ ), and patterns for (C) bacterial, (D) archaeal and (E) viral abundance along the vertical profile of deep-sea sediments. Cell and virus counts were carried out by epifluorescence microscopy (i.e. CARD-FISH for Bacteria and Archaea, Ishii et al. 2004, Molari \& Manini 2012; SYBR Green I staining for viruses, Danovaro et al. 2001, Noble \& Fuhrman 1998). For the determination of the prokaryotic biomass, prokaryotic size was estimated using a micrometer ocular (as maximal length and width), assigning prokaryotic cells into different size classes; prokaryotic biovolumes were then calculated after inter-calibration with measurements conducted with scanning electron microscopy and converted into carbon content assuming $310 \mathrm{fg} \mathrm{C}$ $\mu \mathrm{m}^{-3}$ as a conversion factor (Fry 1988). For viral biomass, the conversion factor of $0.2 \mathrm{fg} \mathrm{C}$ virus $^{-1}$ was used (Wilhelm \& Suttle 1999) bial abundance and biomass, more effort is needed to analyse these trends in more detail in each water depth realm (e.g. meso-, bathy- and abyssopelagic). Indeed, our data suggest a significant increase in microbial abundance and biomass (especially for Archaea) at depths from 4000 to $6000 \mathrm{~m}$ (Fig. 2A,B). However, the number of analysed samples and level of replication in this depth range remain insufficient to draw significant and definitive conclusions.
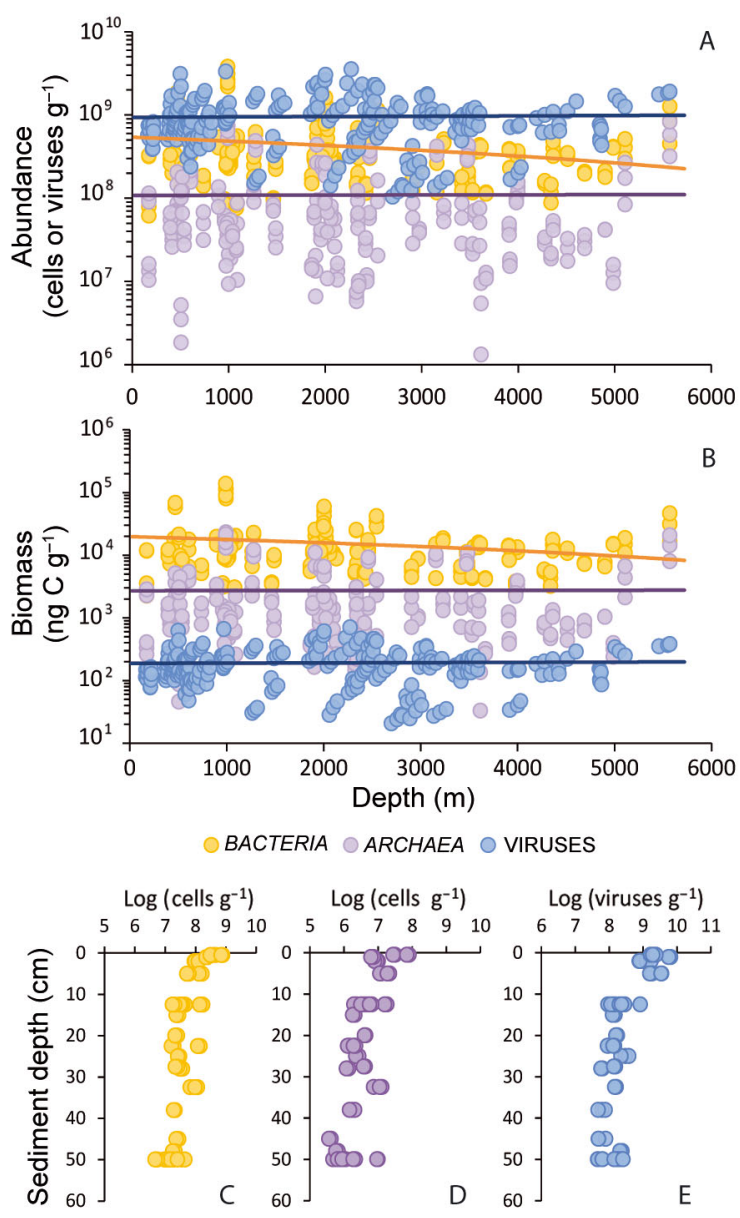
Multiplying the average value of bacterial, archaeal and viral abundance or biomass obtained within a discrete bathymetric range (using $200 \mathrm{~m}$ intervals) by the portion of global surface corresponding to that bathymetric interval, we found a marked increase in the abundance and biomass of all microbial components with increasing water depth (Fig. 3A,B), indicating that the deep seas host the vast majority of the benthic biosphere.

Viruses represent the most abundant biological entities in deep-sea surface sediments, at all water depths investigated so far, on average accounting for $67 \%$ of the overall microbial abundance (Fig. 4A). However, the small size of viruses makes these biological components far less important in terms of biomass than that of Bacteria and Archaea, contributing only 0.5 to $4 \%$ (on average $1.2 \%$ ) to the total micro-
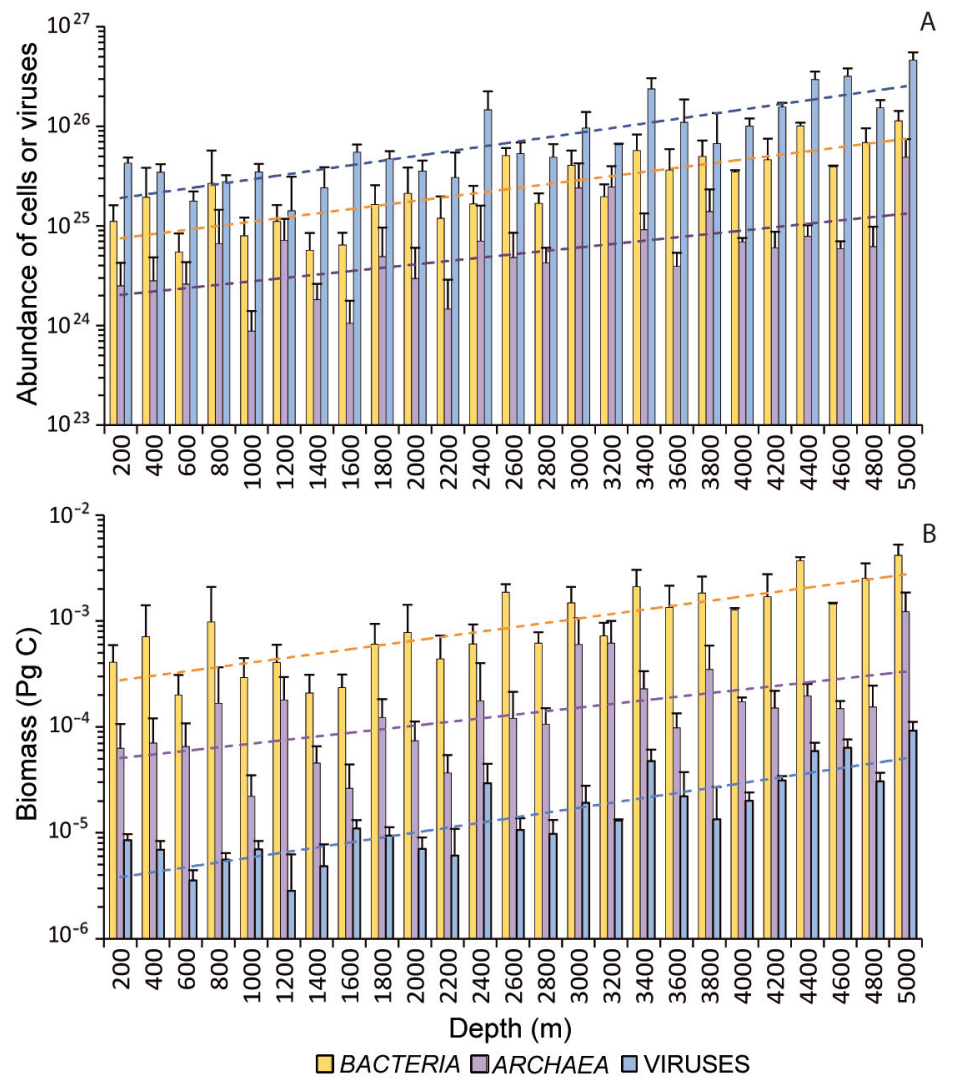

Fig. 3. Total (A) abundance and (B) biomass of Bacteria, Archaea and viruses in the deep seafloor at bathymetric intervals of $200 \mathrm{~m}$. Values were obtained by multiplying the average value of bacterial, archaeal and viral abundance or biomass for each bathymetric interval of $200 \mathrm{~m}$ by the portion of global surface corresponding to that interval. Equations of the fitted lines in panel A: Bacteria- $y=6.84$ $\times 10^{24} \times \mathrm{e}^{0.096 \cdot x}, \mathrm{R}^{2}=0.659$; Archaea-y $=1.88 \times 10^{24} \times \mathrm{e}^{0.078 \cdot x}, \mathrm{R}^{2}=$ 0.364 ; viruses $-y=1.71 \times 10^{25} \times \mathrm{e}^{0.108 \cdot x}, \mathrm{R}^{2}=0.721$. Equations of the fitted lines in panel B: Bacteria- $y=3 \times 10^{-4} \times \mathrm{e}^{0.093 \cdot x}, \mathrm{R}^{2}=0.667$; Archaea-y $=3.64 \times 10^{-5} \times \mathrm{e}^{0.081 \cdot x}, \mathrm{R}^{2}=0.392$; viruses $-y=3.43 \times$ $10^{-6} \times \mathrm{e}^{0.105 \cdot x}, \mathrm{R}^{2}=0.733$. Standard deviations are shown

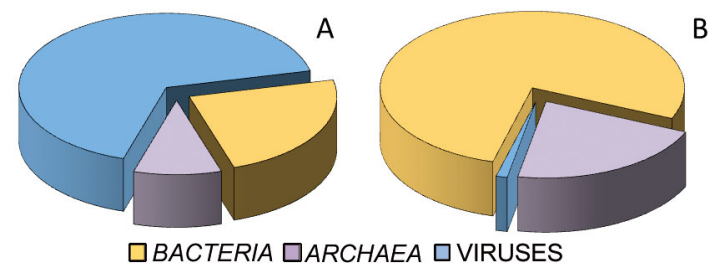

Fig. 4. Relative contribution of Bacteria, Archaea and viruses to the overall microbial (A) abundance and (B) biomass in benthic deep-sea ecosystems. Relative contributions were obtained after calculating the cumulative bacterial, archaeal and viral abundance and biomass values for the seafloor surface (i.e. the sum of the average values for each bathymetric range)

bial biomass (Fig. 4B) if the conversion factor of $0.2 \mathrm{fg}$ C virus ${ }^{-1}$ is used (Wilhelm \& Suttle 1999). Based on a biophysical model and different assumptions, Jover et al. (2014) suggested that the carbon content and thus the contribution of marine viruses to the total microbial biomass could be up to 10 times lower. As such, current research perspectives on marine viruses mainly focus on virus-host interactions influencing global biogeochemistry and virus-host evolution, rather than standing stocks of viral biomass per se (Rohwer \& Thurber 2009, Jover et al. 2014, Dell'Anno et al. 2015). The analysis of the relative contribution of Bacteria, Archaea and viruses to the total microbial abundance and biomass in each bathymetric range did not show clear patterns with increasing water depth (Fig. 5A,B). By integrating the values reported here of abundance and biomass of the 3 microbial components from the top $1 \mathrm{~cm}$ of the sediment down to $50 \mathrm{~cm}$ depth, we estimated the abundance and biomass of Bacteria, Archaea and viruses in surface deep-sea sediments on a global scale. Overall, surface deep-sea sediments host $3.5 \times 10^{28}$ bacterial cells, $1.4 \times 10^{28}$ archaeal cells and $9.8 \times 10^{28}$ viruses, corresponding to $1.29,0.35$ and 0.02 Pg C, respectively.

\section{IMPLICATIONS FOR GLOBAL C CYCLING AND PROVISION OF GOODS AND SERVICES}

Photoautotrophic production in the open ocean accounts for over $80 \%$ of the global oceanic primary production (del Giorgio \& Duarte 2002). Organic particles originating from the surface waters are exported down to 


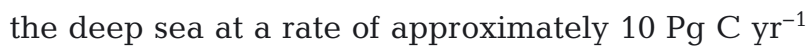
(Duce et al. 2008), but only a small fraction of the particulate organic carbon produced in the ocean surface reaches the ocean seafloor (Muller-Karger et al. 2005, Dunne et al. 2007), mostly composed of organic particles resistant to degradation (Middelburg \& Meysman 2007). Indeed, within the organic matter pool settling on the seafloor, only a minor portion is represented by compounds immediately bioavailable for heterotrophic consumers (Fabiano et al. 1993, 2001, Danovaro et al. 1999). With the average prokaryotic (i.e. bacterial plus archaeal) abundance reported here for marine sediments (approximately 5 $\times 10^{8} \mathrm{~g}^{-1}$, range: $2 \times 10^{8}$ to $2 \times 10^{9} \mathrm{~g}^{-1}$ ) and considering the amounts of total organic carbon generally observed in open ocean sediments (ca. $5 \mathrm{mg} \mathrm{C} \mathrm{g}^{-1}$, Pedersen \& Calvert 1990, Arndt et al. 2013), bacterial and archaeal biomass together contributes, on average, ca. $2 \%$ to the organic carbon pool in surface sediments. Estimates of pools based on CARD-FISH analyses are used conservatively, as these values are generally underestimated when compared to results on total prokaryotic abundance based on SYBR Green staining (Molari et al. 2013).

Prokaryotes are known to duplicate faster than eukaryotic components, resulting in a turnover of the
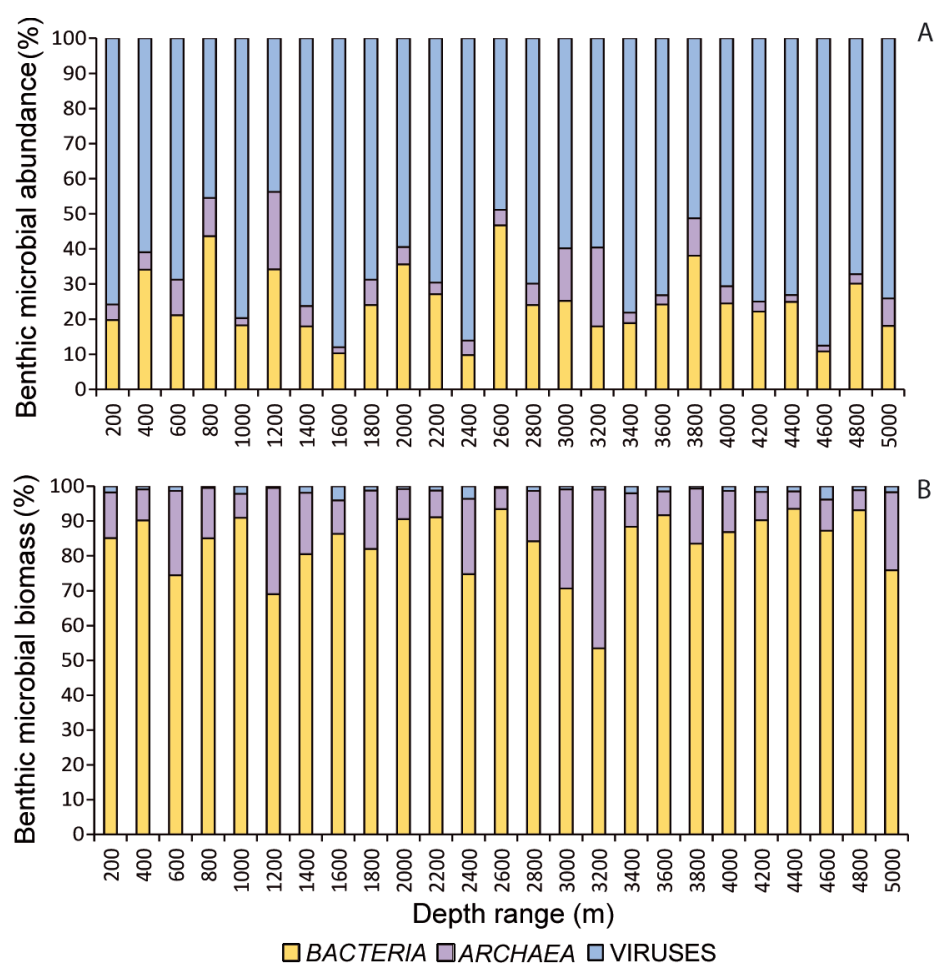

Fig. 5. Relative contribution of Bacteria, Archaea and viruses to the total microbial (A) abundance and (B) biomass in the deep seafloor at bathymetric intervals of $200 \mathrm{~m}$ prokaryotic carbon biomass faster than that of other benthic organisms. Based on present estimates of the overall bacterial and archaeal biomass, and assuming an average turnover time of $20 \mathrm{~d}$ for prokaryotes inhabiting the deep ocean interior (which is a modal value of estimates available in the literature, where the range is $2-100 d_{i}$ Herndl et al. 2005, Danovaro et al. 2008b, Molari et al. 2013), the biomass production in surface deep-sea sediments of the world oceans is

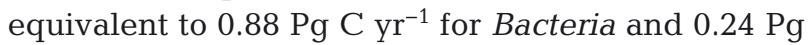
$\mathrm{C} \mathrm{yr}^{-1}$ for Archaea. Hence, if these estimates are correct, the global organic carbon inputs to the ocean

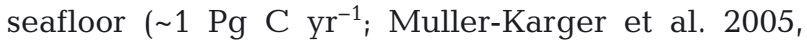
Dunne et al. 2007) are apparently insufficient to sustain microbial metabolism and growth since a large fraction of carbon is also utilized for respiration processes $(50-80 \%$ of the total carbon consumed). Nevertheless, a fraction of organic carbon (approximately $1-10 \mathrm{~kg} \mathrm{C} \mathrm{m}^{-3}$ at the seafloor; Mayer 1993, Arndt et al. 2013), not consumed by heterotrophic organisms (Hedges \& Keil 1995), is buried in the sediments. This apparent paradox of the imbalance between the organic carbon supply and its consumption can be partly explained taking into account the microbial recycling of carbon (Strayer 1988), or with a potential underestimation of the allochthonous inputs of organic carbon (Arístegui et al. 2009, Burd et al. 2010) and/or of the additional sources of organic carbon that are produced in situ through chemoautotrophic processes (Herndl et al. 2008, Reinthaler et al. 2010, Middelburg 2011, Molari et al. 2013, Herndl \& Reinthaler 2013). However, using the model proposed by Strayer (1988), we calculated that the observed overall carbon production can be sustained only for ecological (carbon conversion) efficiency $>45 \%$. This value appears very high for oligotrophic ecosystems, such as the deep seas (del Giorgio \& Cole 1998, Dunne et al. 2007). Moreover, recent evidence suggests that intracellular dissolved material released by viral lysis can be an additional important bioavailable source of organic carbon for sustaining prokaryotic metabolism (Corinaldesi et al. 2007, Danovaro et al. 2008b, Corinaldesi et al. 2014). All of these processes have a profound influence on the budgetary considerations, and are still difficult to model in deepsea ecosystems.

Prokaryotic heterotrophic production and viral production in surface deep-see sediments were demonstrated to be high at all 
depths and were significantly correlated (Danovaro et al. 2008b). This is in line with the theoretical dependence of viral replication on host abundance and metabolism. The impact of viruses on benthic prokaryotes led to the estimation of a virus-induced abatement of $80 \%$ of the total prokaryotic heterotrophic production in deep-sea sediments, increasing with water depth, from 16 to $63 \%$ in coastal surface sediments up to $>80 \%$ in deep-sea surface sediments (at depths $>1000 \mathrm{~m}$ ), indicating that viruses are the main agents of mortality for prokaryotes in deep-sea sediments worldwide (Danovaro et al. 2008b). Indeed, viruses are responsible for the abatement of an important fraction of the benthic prokaryotic biomass at fast rates (Danovaro et al. 2008b), releasing,

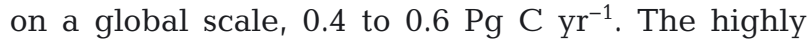
bioavailable organic carbon supplied by viral shunting is estimated to sustain $35 \%$ of the total benthic prokaryotic metabolism, with important implications for carbon cycling and nutrient regeneration processes (including nitrogen and phosphorus associated with prokaryotic biomass, Danovaro et al. 2008b). Viral infections thus play important roles in the functioning of the benthic ecosystem, by controlling benthic prokaryotic biomass (top down, predatory control), by stimulating prokaryotic metabolism (bottom-up mechanism) and by accelerating biogeochemical processes. Despite the recognized role of viruses in the deep seafloor, only scattered information is available on the composition of the active fraction of standing viruses able to infect Bacteria and Archaea, as well as on the host range of the viruses able to replicate in deep-sea sediments (Yoshida et al. 2013).

The dark portions of the oceans represent the most remote biome on Earth, and they are characterized by a huge, yet-to-be-described microbial diversity (Sogin et al. 2006, Zinger et al. 2011, Mengerink et al. 2014), representing one of the last frontiers in scientific research. Deep-sea microbes play crucial roles in the ecosystem at the global scale, significantly contributing to biogeochemical cycles and the regeneration of organic matter and nutrients which can support food webs and keep the ocean healthy and productive. Moreover, the significance of the value of these almost invisible but essential components of the biosphere extends way beyond ecological aspects. Indeed, deep-sea ecosystems have an enormous potential in the discovery and development of new products of microbial origin, such as pharmaceuticals, molecular probes, enzymes, cosmetics, nutritional supplements and agrochemicals. Deep-sea microbes, and particularly those inhabiting extreme ecosystems such as hydrothermal vents, have been fundamental for the discovery of new bioactive molecules subsequently employed for technological and industrial purposes (Ohta \& Hatada 2006, Wu et al. 2006, Cavicchioli et al. 2011). Different enzymes such as DNA polymerases, enzymes involved in ethanol production or others with antioxidant properties, derived from deep-sea Bacteria, are already commercially available. Several secondary metabolites with novel structures and specific bioactivities, which are promising for medical therapy, have been discovered from deep-sea microbes, including alkaloids as therapeutic agents, bone-healing materials and exopolysaccharides with anticoagulant properties (Colliec Jouault et al. 2001, Zanchetta et al. 2003, Yang et al. 2013). Evidence is also accumulating on the importance of microbes on the biomineralisation and transformation of deep-sea polymetallic nodules and metal crusts, whose economic value is currently of great industrial and technological interest (Wang et al. 2011). Thus, the knowledge of deep-sea ecosystems and their microbial components is important not only because of their key role in biogeochemical cycles, but also because they provide unique goods and services which can be exploited for human socio-economic development (Thurber et al. 2014). The enormous value of deep-sea ecosystems in terms of exploitable resources highlights the need to establish shared criteria governing their sustainable use and preservation (Mengerink et al. 2014, Van Dover et al. 2014). Human activities such as trawling, deep-sea mining, drilling and dumping (Ramirez-Llodra et al. 2013, Yanagawa et al. 2013, Pusceddu et al. 2014) are profoundly threatening deep-sea ecosystems. Moreover, we must take into account that, if not properly regulated, recent research fields such as deep-sea bioprospecting (i.e. the screening of deep-sea microbes in search of new products of possible economical interest) could potentially generate impacts, similarly to any other kind of exploitation of the deep sea. To date, a legal framework for the management, sharing of the benefits and access to the resources stored in areas beyond national jurisdictions does not exist (Barbier et al. 2014), but this appears to be of fundamental importance to preserve the deep seas, their astonishing microbial biodiversity and their key role in global ecosystem functioning.

Acknowledgements. This research was conducted within the frame of the EU Project MIDAS (Managing Impacts of Deep-seA reSource exploitation), and supported by the FIRB Project EXPLODIVE and by the Flagship Project RIT- 
MARE of the National Research Council of the Italian Ministry Research (MIUR). We thank 3 anonymous reviewers for their useful comments which improved the quality of this manuscript.

\section{LITERATURE CITED}

Alongi DM (1990) Bacterial growth rates, production and estimates of detrital carbon utilization in deep-sea sediments of the Solomon and Coral Seas. Deep-Sea Res A 37:731-746

> Anderson RE, Brazelton WJ, Baross JA (2013) The deep viriosphere: assessing the viral impact on microbial community dynamics in the deep subsurface. Rev Mineral Geochem 75:649-675

Arístegui J, Gasol JM, Duarte CM, Herndl GJ (2009) Microbial oceanography of the dark ocean's pelagic realm. Limnol Oceanogr 54:1501-1529

Arndt S, Jørgensen BB, LaRowe DE, Middelburg JJ, Pancost R, Regnier P (2013) Quantifying the degradation of organic matter in marine sediments: a review and synthesis. Earth Sci Rev 123:53-86

Barbier EB, Moreno-Mateos D, Rogers AD, Aronson J and others (2014) Protect the deep sea. Nature 505:475-477

Benecke W (1933) Bakteriologie des Meeres. Handb Biol Arbeitsmethoden 9:717-854

> Biddle JF, Lipp JS, Lever MA, Lloyd KG and others (2006) Heterotrophic Archaea dominate sedimentary subsurface ecosystems off Peru. Proc Natl Acad Sci USA 103: 3846-3851

> Boetius A, Damm E (1998) Benthic oxygen uptake, hydrolytic potentials and microbial biomass at the Arctic continental slope. Deep-Sea Res I 45:239-275

Burd AB, Hansell DA, Steinberg DK, Anderson TR and others (2010) Assessing the apparent imbalance between geochemical and biochemical indicators of meso- and bathypelagic biological activity: What is wrong with present calculations of carbon budgets? Deep-Sea Res II 57:1557-1571

Cavanaugh CM (1985) Symbioses of chemoautotrophic bacteria and marine invertebrates from hydrothermal vents and reducing sediments. Bull Biol Soc Wash 6:373-388

Cavicchioli R, Charlton T, Ertan H, Omar SM, Siddiqui KS, Williams TJ (2011) Biotechnological uses of enzymes from psychrophiles. Microb Biotechnol 4:449-460

Colliec Jouault S, Chevolot L, Helley D, Ratiskol J and others (2001) Characterization, chemical modifications and in vitro anticoagulant properties of an exopolysaccharide produced by Alteromonas infernus. Biochim Biophys Acta 1528:141-151

Corinaldesi C, Dell'Anno A, Danovaro R (2007) Viral infection plays a key role in extracellular DNA dynamics in marine anoxic systems. Limnol Oceanogr 52:508-516

Corinaldesi C, Tangherlini M, Luna GM, Dell'Anno A (2014) Extracellular DNA can preserve the genetic signatures of present and past viral infection events in deep hypersaline anoxic basins. Proc Soc B: Biol Sci 281:20133299

Cragg BA, Parkes RJ, Fry JC, Herbert RA, Wimpenny JWT, Getliff JM (1990) Bacterial biomass and activity profiles within deep sediment layers. In: Suess E, von Huene R and the Shipboard Scientific Party (eds) Proceedings of the Ocean Drilling Program, Scientific Results, Vol 112. Ocean Drilling Program, College Station, TX, p 607-619 D'Hondt S, Rutherford S, Spivack AJ (2002) Metabolic activ- ity of subsurface life in deep-sea sediments. Science 295: 2067-2070

D'Hondt S, Jørgensen BB, Miller DJ, Batzke A and others (2004) Distributions of microbial activities in deep subseafloor sediments. Science 306:2216-2221

Danovaro R, Marrale D, Della Croce N, Dell'Anno A, Fabiano $M$ (1998) Heterotrophic nanoflagellates, bacteria, and labile organic compounds in continental shelf and deep-sea sediments of the Eastern Mediterranean. Microb Ecol 35:244-255

Danovaro R, Marrale D, Della Croce N, Parodi P, Fabiano M (1999) Biochemical composition of sedimentary organic matter and bacterial distribution in the Aegean Sea: trophic state and pelagic-benthic coupling. J Sea Res 42: 117-129

Danovaro R, Dell'Anno A, Trucco A, Vannucci S (2001) Determination of virus abundance in marine sediments. Appl Environ Microbiol 67:1384-1387

> Danovaro R, Corinaldesi C, Filippini M, Fischer UR and others (2008a) Viriobenthos in freshwater and marine sediments: a review. Freshw Biol 53:1186-1213

> Danovaro R, Dell'Anno A, Corinaldesi C, Magagnini M, Noble R, Tamburini C, Weinbauer M (2008b) Major viral impact on the functioning of benthic deep-sea ecosystems. Nature 454:1084-1087

Danovaro R, Snelgrove PV, Tyler P (2014) Challenging the paradigms of deep-sea ecology. Trends Ecol Evol 29: 465-475

del Giorgio PA, Cole JJ (1998) Bacterial growth efficiency in natural aquatic systems. Annu Rev Ecol Syst 29:503-541

del Giorgio PA, Duarte CM (2002) Respiration in the open ocean. Nature 420:379-384

> Dell'Anno A, Danovaro R (2005) Extracellular DNA plays a key role in deep-sea ecosystem functioning. Science 309: 2179

Dell'Anno A, Corinaldesi C, Danovaro R (2015) Virus decomposition provides an important contribution to benthic deep-sea ecosystem functioning. Proc Natl Acad Sci 112:E2014-E2019

Deming JW, Baross JA (1993) The early diagenesis of organic matter: bacterial activity. In: Engel MH, Macko SA (eds) Organic geochemistry. Plenum Press, New York, NY, p 119-144

Duce RA, LaRoche J, Altieri K, Arrigo KR and others (2008) Impacts of atmospheric anthropogenic nitrogen on the open ocean. Science 320:893-897

> Dunne JP, Sarmiento JL, Gnanadesikan A (2007) A synthesis of global particle export from the surface ocean and cycling through the ocean interior and on the seafloor. Global Biogeochem Cycles 21, GB4006, doi:10.1029/ 2006GB002907

Engelhardt T, Kallmeyer J, Cypionka H, Engelen B (2014) High virus-to-cell ratios indicate ongoing production of viruses in deep subsurface sediments. ISME $\mathrm{J}$ 8: 1503-1509

> Fabiano M, Povero P, Danovaro R (1993) Distribution and composition of particulate organic matter in the Ross Sea (Antarctica). Polar Biol 13:525-533

Fabiano M, Pusceddu A, Dell'Anno A, Armeni M and others (2001) Fluxes of phytopigments and labile organic matter to the deep ocean in the NE Atlantic Ocean. Prog Oceanogr 50:89-104

Fry JC (1988) Determination of biomass. In: Austin B (ed) Methods in aquatic bacteriology. John Wiley \& Sons, Chichester, p 27-72 
Fuhrman JA (1999) Marine viruses and their biogeochemical and ecological effects. Nature 399:541-548

Gage JD, Tyler PA (1991) Deep-sea biology: a natural history of organisms at the deep-sea floor. Cambridge University Press, Cambridge

Hedges JI, Keil RG (1995) Sedimentary organic matter preservation: an assessment and speculative synthesis. Mar Chem 49:81-115

Herndl GJ, Reinthaler T (2013) Microbial control of the dark end of the biological pump. Nat Geosci 6:718-724

Herndl GJ, Reinthaler T, Teira E, van Aken H, Veth C, Pernthaler A, Pernthaler J (2005) Contribution of Archaea to total prokaryotic production in the deep Atlantic Ocean. Appl Environ Microbiol 71:2303-2309

> Herndl GJ, Agogué H, Baltar F, Reinthaler T, Sintes E, Varela MM (2008) Regulation of aquatic microbial processes: the 'microbial loop' of the sunlit surface waters and the dark ocean dissected. Aquat Microb Ecol 53: 59-68

> Hoehler TM, Jørgensen BB (2013) Microbial life under extreme energy limitation. Nat Rev Microbiol 11: 83-94

- Ishii K, Mußmann M, MacGregor BJ, Amann R (2004) An improved fluorescence in situ hybridization protocol for the identification of bacteria and archaea in marine sediments. FEMS Microbiol Ecol 50:203-213

> Jannasch HW, Taylor CD (1984) Deep-sea microbiology. Annu Rev Microbiol 38:487-514

Jørgensen BB, Boetius A (2007) Feast and famine - microbial life in the deep-sea bed. Nat Rev Microbiol 5:770-781

> Jover LF, Effler TC, Buchan A, Wilhelm SW, Weitz JS (2014) The elemental composition of virus particles: implications for marine biogeochemical cycles. Nat Rev Microbiol 12:519-528

Kallmeyer J, Pockalny R, Adhikari RR, Smith DC, D'Hondt S (2012) Global distribution of microbial abundance and biomass in subseafloor sediment. Proc Natl Acad Sci USA 109:16213-16216

Karner MB, DeLong EF, Karl DM (2001) Archaeal dominance in the mesopelagic zone of the Pacific Ocean. Nature 409:507-510

Kato C (2011) Cultivation methods for piezophiles. In: Horikoshi K, Antranikian G, Bull AT, Robb FT, Stetter KO (eds) Extremophiles handbook. Springer, Tokyo, p 719-726

> Lipp JS, Morono Y, Inagaki F, Hinrichs KU (2008) Significant contribution of Archaea to extant biomass in marine subsurface sediments. Nature 454:991-994

Lloyd KG, May MK, Kevorkian R, Steen AD (2013) Meta analysis of quantification methods shows archaea and bacteria to be similarly abundant in the subseafloor. Appl Environ Microbiol 79:7790-7799

Lutz MJ, Caldeira K, Dunbar RB, Behrenfeld MJ (2007) Seasonal rhythms of net primary production and particulate organic carbon flux to depth describe the efficiency of biological pump in the global ocean. J Geophys Res 112, C10011, doi:10.1029/2006JC003706

> Mason OU, Di Meo-Savoie CA, Van Nostrand JD, Zhou J, Fisk MR, Giovannoni SJ (2009) Prokaryotic diversity, distribution, and insights into their role in biogeochemical cycling in marine basalts. ISME J 3:231-242

Mayer L (1993) Organic matter at the sediment-water interface. In: Engel MH, Macko SA (eds) Organic geochemistry: principles and applications. Plenum, New York, NY, p 171-184
Mengerink KJ, Van Dover CL, Ardron J, Baker M and others (2014) A call for deep-ocean stewardship. Science 344: 696-698

Middelboe M, Glud RN, Wenzhöfer F, Oguri K, Kitazato H (2006) Spatial distribution and activity of viruses in the deep-sea sediments of Sagami Bay, Japan. Deep-Sea Res I 53:1-13

> Middelboe M, Glud RN, Filippini M (2011) Viral abundance and activity in the deep sub-seafloor biosphere. Aquat Microb Ecol 63:1-8

Middelburg JJ (2011) Chemoautotrophy in the ocean. Geophys Res Lett 38, L24604, doi:10.1029/2011GL049725

Middelburg JJ, Meysman FJR (2007) Burial at sea. Science 316:1294-1295

> Molari M, Manini E (2012) Reliability of CARD-FISH procedure for enumeration of Archaea in deep-sea surficial sediments. Curr Microbiol 64:242-250

> Molari M, Manini E, Dell'Anno A (2013) Dark inorganic carbon fixation sustains the functioning of benthic deep-sea ecosystems. Global Biogeochem Cycles 27:212-221

Mora C, Danovaro R, Loreau M (2014) Alternative hypotheses to explain why biodiversity-ecosystem functioning relationships are concave-up in some natural ecosystems but concave-down in manipulative experiments. Sci Rep 4:5427

Muller-Karger FE, Varela R, Thunell R, Luerssen R, Hu C, Walsh JJ (2005) The importance of continental margins in the global carbon cycle. Geophys Res Lett 32, L01602, doi:10.1029/2004GL021346

> Nealson KH (1997) Sediment bacteria: Who's there, what are they doing, and what's new? Annu Rev Earth Planet Sci 25:403-434

> Noble RT, Fuhrman JA (1998) Use of SYBR Green I for rapid epifluorescence counts of marine viruses and bacteria. Aquat Microb Ecol 14:113-118

Ohta Y, Hatada YA (2006) A novel enzyme, lambdacarrageenase, isolated from a deep-sea bacterium. J Biochem 140:475-481

Parkes RJ, Cragg BA, Wellsbury P (2000) Recent studies on bacterial populations and processes in marine sediments: a review. Hydrogeol J 8:11-28

Pedersen TF, Calvert SE (1990) Anoxia vs. productivity: What controls the formation of organic-carbon-rich sediments and sedimentary rocks? AAPG Bull 74:454-466

> Proctor LM, Fuhrman JA (1990) Viral mortality of marine bacteria and cyanobacteria. Nature 343:60-62

Pusceddu A, Bianchelli S, Martín J, Puig P, Palanques A, Masqué P, Danovaro R (2014) Chronic and intensive bottom trawling impairs deep-sea biodiversity and ecosystem functioning. Proc Natl Acad Sci USA 111:8861-8866

> Ramirez-Llodra E, Brandt A, Danovaro R, De Mol B and others (2010) Deep, diverse and definitely different: unique attributes of the world's largest ecosystem. Biogeosciences 7:2851-2899

- Ramirez-Llodra E, De Mol B, Company JB, Coll M, Sardà F (2013) Effects of natural and anthropogenic processes in the distribution of marine litter in the deep Mediterranean Sea. Prog Oceanogr 118:273-287

Reinthaler T, van Aken HM, Herndl GJ (2010) Major contribution of autotrophy to microbial carbon cycling in the deep North Atlantic's interior. Deep-Sea Res II 57: 1572-1580

Rex MA, Etter RJ, Morris JS, Crouse J and others (2006) Global bathymetric patterns of standing stock and body size in the deep-sea benthos. Mar Ecol Prog Ser 317:1-8 
Rohwer F, Thurber RV (2009) Viruses manipulate the marine environment. Nature 459:207-212

Schippers A, Neretin LN (2006) Quantification of microbial communities in near-surface and deeply buried marine sediments on the Peru continental margin using realtime PCR. Environ Microbiol 8:1251-1260

Schippers A, Neretin LN, Kallmeyer J, Ferdelman TG, Cragg BA, Parkes RJ, Jørgensen BB (2005) Prokaryotic cells of the deep subsurface biosphere identified as living bacteria. Nature 433:861-864

Siem-Jørgensen M, Glud RN, Middelboe M (2008) Viral dynamics in a coastal sediment: seasonal pattern, controlling factors and relations to the pelagic-benthic coupling. Mar Biol Res 4:165-179

Smith CR, Berelson W, Demaster DJ, Dobbs FC and others (1997) Latitudinal variations in benthic processes in the abyssal equatorial Pacific: control by biogenic particle flux. Deep-Sea Res II 44:2295-2317

Sogin ML, Morrison HG, Huber JA, Mark Welch D and others (2006) Microbial diversity in the deep sea and the underexplored 'rare biosphere'. Proc Natl Acad Sci USA 103:12115-12120

Strayer D (1988) On the limits to secondary production. Limnol Oceanogr 33:1217-1220

Suttle CA (2005) Viruses in the sea. Nature 437:356-361

Suttle CA (2007) Marine viruses-major players in the global ecosystem. Nat Rev Microbiol 5:801-812

Teske AP (2005) The deep subsurface biosphere is alive and well. Trends Microbiol 13:402-404

> Thurber AR, Sweetman AK, Narayanaswamy BE, Jones DOB, Ingels J, Hansman RL (2014) Ecosystem function and services provided by the deep sea. Biogeosciences 11:3941-3963

Van Dover CL, Aronson J, Pendleton L, Smith S and others (2014) Ecological restoration in the deep sea: Desiderata. Mar Policy 44:98-106

Wang X, Wiens M, Schröder HC, Schloßmacher U, Müller WEG (2011) Molecular biomineralization: toward an understanding of the biogenic origin of polymetallic nodules, seamount crusts, and hydrothermal vents. In: Müller WEG (ed) Molecular biomineralization. Springer, Berlin, p 77-110

Editorial responsibility: Fereidoun Rassoulzadegan, Villefranche-sur-Mer, France
Wei CL, Rowe GT, Briones EE, Boetius A and others (2010) Global patterns and predictions of seafloor biomass using random forests. PLoS ONE 5:e15323

Whitman WB, Coleman DC, Wiebe WJ (1998) Prokaryotes: the unseen majority. Proc Natl Acad Sci USA 95: 6578-6583

Wilhelm SW, Suttle CA (1999) Viruses and nutrient cycles in the sea. BioScience 49:781-788

Wu S, Liu B, Zhang X (2006) Characterization of a recombinant thermostable xylanase from deep-sea thermophilic Geobacillus sp. MT-1 in East Pacific. Appl Microbiol Biotechnol 72:1210-1216

> Xie S, Lipp JS, Wegener G, Ferdelman TG, Hinrichs KU (2013) Turnover of microbial lipids in the deep biosphere and growth of benthic archaeal populations. Proc Natl Acad Sci USA 110:6010-6014

> Yanagawa K, Nunoura T, McAllister SM, Hirai M and others (2013) The first microbiological contamination assessment by deep-sea drilling and coring by the D/V Chikyu at the Iheya North hydrothermal field in the Mid-Okinawa Trough (IODP Expedition 331). Front Microbiol 4 : 327

> Yang XW, Zhang GY, Ying JX, Yang B and others (2013) Isolation, characterization, and bioactivity evaluation of 3((6-methylpyrazin-2-yl)methyl)-1H-indole, a new alkaloid from a deep-sea-derived actinomycete Serinicoccus profundi sp. nov. Mar Drugs 11:33-39

Yayanos AA (1995) Microbiology to 10,500 meters in the deep sea. Annu Rev Microbiol 49:777-805

> Yoshida M, Takaki Y, Eitoku M, Nunoura T, Takai K (2013) Metagenomic analysis of viral communities in (hado) pelagic sediments. PLoS ONE 8:e57271

> Zanchetta P, Lagarde N, Guezenne J (2003) A new bonehealing material: a hyaluronic acid-like bacterial exopolysaccharide. Calcif Tissue Int 72:74-79

Zinger L, Amaral-Zettler LA, Fuhrman JA, Horner-Devine MC and others (2011) Global patterns of bacterial betadiversity in seafloor and seawater ecosystems. PLoS ONE 6:e24570

ZoBell CE, Morita RY (1959) Deep-sea bacteria. Galathea Rep Copenhagen 1:139-154

Submitted: November 17, 2014; Accepted: February 17, 2015 Proofs received from author(s): April 30, 2015 